\title{
ANALYSIS OF STUDENTS ERROR ACCORDING TO NEWMAN IN SOLVING MATHEMATICS PROBLEMS OF ALGEBRA IN THE FORM OF STORY IN SECOND GRADE OF SMPN 1 BANDA ACEH
}

\author{
Johan Yunus ${ }^{1}$, Bintang Zaura ${ }^{2}$, Yuhasriati ${ }^{3}$ \\ Department of Mathematic Education, Syiah Kuala University \\ E-mail: jolimpok@yahoo.com
}

Diterima: 09/08/2019; Disetujui: 30/08/2019

\begin{abstract}
One of the material in mathematics lesson is algebra operation. Algebraic materials require the students to master the concept of algebra that becomes the basis for learning the next material. However, students still make mistakes in solving problems related to algebra operations. Includes the problem solving form of the story problem that adds difficulties for students. The purpose of this study is to find out what the mistakes and causes of mistakes made by students of class VIII SMP Negeri 1 Banda Aceh in solving the story based on Newman procedures. The approach used is a qualitative approach with the type of research is descriptive. Data collection using tests and interviews. The research involves students VIII-1, amounting to 27 students. Subjects of interview research taken 3 of 27 students class VIII-1, with the criteria of students who do alot errors. Each subject was interviewed related to the results of his work on the algebra operation about story problem. The validity test of the data was done by triangulation technique. The results of the research indicate that the type of mistakes made by the students of grade VIII-1 SMP Negeri 01 Banda Aceh in solving the algebraic story problem are misunderstanding, transforming mistakes, processing skill mistakes, and the error of writing the final answer. Misunderstanding caused by the students forgetting and rushing in doing the problem. The problem of transformation is caused by the weakness of the student's ability to change the story into algebra and wrong in using the approach. The error of process skill is caused wrongly in calculating algebraic operations. While the error of writing the final answer caused the students did not make conclusions and did not write the final outcome of the settlement. The implication of this study is the need for further research to reduce the students in making the same mistakes. Further research is also needed on the work that students can do to overcome the mistakes made by students as can be seen in this study.
\end{abstract}

Kata Kunci: Student Error, Newman, Algebra Story Problem. 


\section{BACKGROUND}

Education is very important in life. Education occurs since a person was born and will continue to grow along with the times. This is in accordance with the opinion of Tirtarahardja (2005:82), "Education is universal something 1 and continues uninterrupted from generation to generation anywhere in the world". So it can be concluded that education is an obligation that we get since from birth and will take place continuously. Education types consist of formal, non-formal and informal education (Law No. 20 of 2003). In this case formal education can be obtained students at school. One of the subjects taught at the level of education in school is mathematics.

Soedjadi (2000) stated, "Mathematics learning is given in all schools, both in primary and secondary education". Thus, mathematics is one of the fields of study that students learn when in junior high school. Mathematics education in junior high school will be the basis for studying math in high school even up to the next level. Therefore, the mastery of mathematics need to be improved, because it is a very important science in various education sciences.

One of the characteristics of mathematics is the deductive mindset (Soedjadi, 2000). Deductive thinking can be said to be a general idea which is then applied or directed to a special thing. So, in learning mathematics is not only required to master mathematical concepts but students are also required to be able to apply the concept in solving everyday problems. In algebraic material there are problems in the form of a story. In this case, to solve the problems of Algebraic Operations students are required to master the concept of algebra that has been taught at the previous level. But not a few students who get constraints and consider the story of algebraic operations difficult, so that students make mistakes in solving them. Especially with the problems of algebra in the form of story must change the form of problems into a mathematical model, so that will add difficulties for students in the solution of the problem. This is supported by the results of
Zahara (2015) research that the errors made by students in solving algebra operation problem is a mistake of principle, concept, and verbal. Verbal error caused by students do not understand in translating into the form of mathematical model.

To solve the problem and help the students in solving the story problem it is necessary to analyze the mistakes made by the students. One method that can analyze the mistakes made by students in solving the story problem is by using Newman's error analysis method. In Newman's method suggest five stages that can help to analyze the mistakes made by students during solving the story problem. The students' mistakes in doing mathematical story problems are divided into five types of errors: read error, comprehension error, transformation error, process skills error, and errors in the solving process (end coding error) (White, 2010). Therefore, the researcher is interested to do the research of student error analysis according to Newman in solving the mathematical problem of algebraic material. The question of research in this study is what are the errors and causes of the students make a mistake in solving the problem of algebra operation of the story form based on Newman's error analysis method in the students of second grade in SMP 1 Banda Aceh? The goal to be achieved in this research is to know any errors and causes of students to make mistakes in solving the problem of algebra operation of the story form based on the Newman's error analysis method for the students of second grade in SMP 1 Banda Aceh.

The terms mathematics (English), mathematics (German), mathematique (French), matematico (Italian), matematiceski (Russian), or mathematic (Dutch) are derived from the Greek mathematike, meaning "relating to learning". Mathematics as one of the basic science, today has developed in such a way so rapidly, both material and its usefulness, so that not all experts can understand mathematics. Mathematics is very important in life, realizing that then math lesson is needed and will be a 
thing so prioritized by humans. Thus the learning of mathematics is a way of thinking and reasoning that is used to solve various types of problems in life.

Problem of story is a matter written with sentences of stories that are converted into mathematical sentences or mathematical equations. Problem of Story using everyday sentences that are easy to understand and meaningful. Using story in the school is meant that students are able to solve problems in everyday life. According to Ashlock (Setiyawati, 2011: 18) "the story is a matter that can be presented in the form of oral and written, the story in the form of writing a sentence that illustrates the activities in everyday life. Taken from everyday life with the experience of students so as to make students more master or understand the purpose of the matter.

The Newman procedure is a method for analyzing errors in problem solving (Jha, 2012: 17). According to Prakitipong and Nakamura (2006: 113) In the process of problem solving, there are many factors that support students to get the right answer. This method states that in solving the problem there are two types of obstacles that prevent students from achieving the right answer, namely: (1) problems in reading and understanding the concepts expressed in the reading and understanding of the problem, and (2) problems in the calculation process consisting on transformation, processing skills, and writing answers. Newman also revealed that there are five stages that students must do in working on problems in the story (White, 2010: 133), namely (1) reading the problem (reading); (2) comprehension (comprehension); transformation of the problem (transformation); (4) process skills; (5) the writing of the final answer (end coding).

To find out the factors causing student error in solving the story problem can be known from the mistakes made by the students. Based on what happens in the process of learning about the story in school the factors causing student error can be described as follows: (a) Lack of ability of students in reading problems, thus causing the students to be less aware of the expected answer request in the solution of the
Analysis of Students Error According to Newman In Solving Mathematics Problems Of Algebra In The Form Of Story In Second Grade Of SMPN 1 Banda Aceh

Johan Yunus, Bintang Zaura, Yuhasriati

problem. The point is that students do not understand the problem so students do not understand about the contents of the matter. (b) Lack of student mastery related to formulas, properties, and workmanship in solving the problem. So, in solving the problem students often forget in the use of the formula. (c) In working on the problem, students often experience mistakes due to lack of awareness of students in checking the final answer. (d) Insufficient interest in mathematics lessons or insufficiency of students in learning.

Based on the location of the error, the factors causing errors caused by cognitive and non-cognitive factors and the solution of the problem according to Newman, then in this study are: (1) Factors causing reading errors is when students do not understand the meaning of words on the problem. (2) Factors that cause misunderstanding, students do not understand the problem in the matter so that students cannot determine what is known and asked questions. (3) The factor causing the transformation error, the student has understood the problem but cannot change the matter into a mathematical form. (4) Factor of cause of process skill mistake that is student cannot solve problem because student do not understand procedure of number operation in solving problem. (5) Factors causing the error of writing the final answer, the student has done all the steps of the procedure appropriately, but the habit of solving the story problem without returning the model answer to answer the problem asked questions.

\section{RESEARCH METHODOLOGY}

The approach used in this study is a qualitative approach that is to know where the location and the cause of the students in solving the problem of story form of Algebra operation. Moleong (2005: 10) said that qualitative research has inductive properties and prioritize the concept rather than result. As for, the type of research is descriptive because it describes the mistakes which students make for what they are by regularly reviewing and being done carefully.

This research was conducted in SMPN 1 Banda Aceh. The research involved the students VIII-1 which amounted to 27 students. Subject 
Analysis of Students Error According to Newman In Solving Mathematics Problems Of Algebra In The Form Of Story In Second Grade Of SMPN 1 Banda Aceh

Johan Yunus, Bintang Zaura, Yuhasriati

research interview was taken 3 of 27 students of class VIII-1, with the criteria of students who make many mistakes. Each research subject was interviewed related to the results of his work on about the story of algebra operations. Test data validity is done with triangulation technique. Data collection using test and interview. Interview conducted by researcher with 6 students who make mistakes in solving algebraic matter material story to know what factors cause students to make mistakes based on students Newman analysis.

Table 1. Indicator of students' errors

\begin{tabular}{|c|c|}
\hline Nerrman Procedure & Indicator \\
\hline $\begin{array}{l}\text { Reading the problem } \\
\text { (Reading) }\end{array}$ & $\begin{array}{l}\text { a. Students can read or recognize symbols or keywords in question. } \\
\text { b. Students interpret the meaning of every word, tem or symbol in the } \\
\text { matter. }\end{array}$ \\
\hline $\begin{array}{l}\text { Comprehen the problem } \\
\text { (Comprehension) }\end{array}$ & $\begin{array}{l}\text { a. Students understand what is known. } \\
\text { b. Students understand what is being asked. }\end{array}$ \\
\hline $\begin{array}{l}\text { Transfoming the problem } \\
\text { (Transformation) }\end{array}$ & $\begin{array}{l}\text { a. Students know what fomulas will be used to solve the problem. } \\
\text { b. Students know the counting operation that will be used. } \\
\text { c. Students can create a mathematical model of the problem presented }\end{array}$ \\
\hline Process Skill & $\begin{array}{l}\text { a. Students know the procedure or steps that will be used to solve the } \\
\text { problem. } \\
\text { b. Students can explain the procedure or steps used to solve the problem. } \\
\text { c. Students can find the final result according to the procedure or the steps } \\
\text { used to solve the problem }\end{array}$ \\
\hline $\begin{array}{l}\text { Winting of the final answer } \\
\text { (Encoding) }\end{array}$ & $\begin{array}{l}\text { a. The student can show the final answer of the problem solving. } \\
\text { b. Students can wite the final answer in accordance rith the conclusion in } \\
\text { question. }\end{array}$ \\
\hline
\end{tabular}

(source: Jha (2012) and Singh (2010))

\section{RESULT}

As for the types of mistakes made by students which is looked at the value of each item of the student's work done. Percentage is tabulated and presented in table 4.3 as follows. Table 2. Percentage of Students Error Based on Newman Procedure

\begin{tabular}{|c|c|c|c|c|c|c|c|c|c|c|c|}
\hline \multirow{3}{*}{$\begin{array}{l}\text { No } \\
1\end{array}$} & \multicolumn{10}{|c|}{ JenisReralahan Dan Persentase } & \multirow{3}{*}{$\begin{array}{l}\text { Ih } \\
46\end{array}$} \\
\hline & \multicolumn{2}{|c|}{ Reading } & \multicolumn{2}{|c|}{ Comprehension } & \multicolumn{2}{|c|}{ Transformation } & \multicolumn{2}{|c|}{ Process Skill } & \multicolumn{2}{|c|}{ Endending } & \\
\hline & . & . & . & . & 12 & $44,44 \%$ & 12 & $44,44 \%$ & 22 & $81,48 \%$ & \\
\hline 2 & $\cdot$ & $\cdot$ & . & . & 17 & $62,96 \%$ & 25 & $92,59 \%$ & 25 & $92,59 \%$ & 67 \\
\hline 3 & . & . & . & . & 5 & $18,51 \%$ & 4 & $14,81 \%$ & 8 & $29,62 \%$ & 17 \\
\hline 4 & $\cdot$ & . & - & . & 8 & $29,62 \%$ & 4 & $14,81 \%$ & 9 & $33,33 \%$ & 21 \\
\hline $\bar{x}$ & & $\cdot$ & & & & $38,88 \%$ & & $41,66 \%$ & & $59,26 \%$ & \\
\hline
\end{tabular}

Based on Table 4.3, of the 27 students who took the test showed that no students made mistakes in the reading of the problem (reading).
There are $18,51 \%$ of students make mistakes in comprehension. $38,88 \%$ of students make mistakes in transformation, $41.66 \%$ of students make mistakes in process skills, and $59.26 \%$ of students make a mistake in writing the final answer (End-coding).

Based on the results of the evaluation, it is taken 3 research subjects who made the mistake at most. The results of the research subject's work selected 1 problem for the analysis. Each research subject analyzed the results of the test work, then conducted based on interviews.

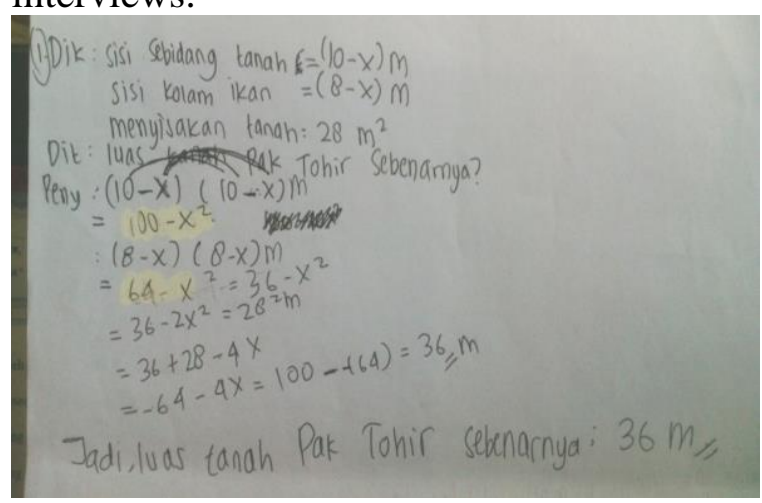

Picture 1 Answer no. 1 research subject 1

Based on the result of the S1 ( $1^{\text {st }}$ subject) work analysis, it is known that $\mathrm{S} 1$ did not perform the Newman procedure of the 3rd stages of the transformation phase. So the S1 did not know what approach to do when completing the problem. Then $S 1$ on stage 4, the stage of process ability, $\mathrm{S} 1$ also made mistakes. The error occurs because $\mathrm{S} 1$ did not perform the calculation process correctly. S1 wrong with multiplication done in the calculation process. Then the final result obtained S1 will also be wrong. Overall, S1 has written the last stages of Newman's procedure, which is writing the final answer on item number 1 , even though the answer written by $\mathrm{S} 1$ is wrong. 


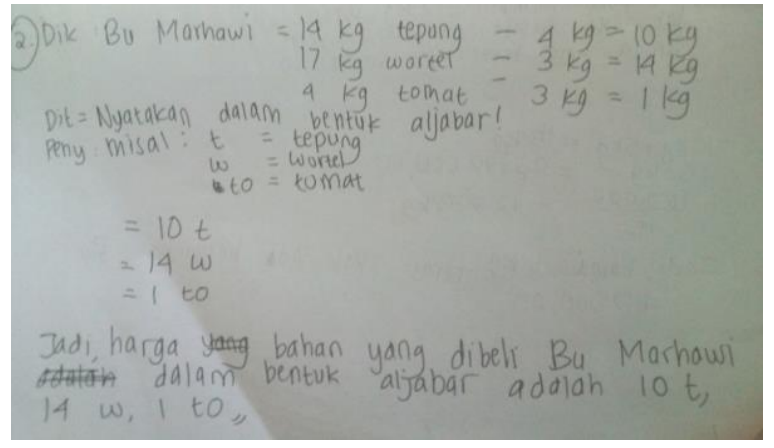

Picture 2 Answer no. 2 research subject 1

Based on the results of the S1 work analysis, it is known that $\mathrm{S} 1$ did not perform the Newman's $3^{\text {rd }}$ stage procedure that is in the transformation stage, S1 made a mistake that is wrong in transforming the problem, it was not in accordance with the command. The possibility of that happening because S1 was not careful in reading the problem. At the $4^{\text {th }}$ stage, the ability of the process seen that $\mathrm{S} 1$ made a mistake. This happens because $\mathrm{S} 1$ was less careful in understanding the given problem of stating the price of materials purchased Mrs. Marhawi in the form of algebra. Because of this error then the final answer obtained S1 certainly wrong. Overall, S1 did not make mistakes in writing answer about the number 2, although the final answer written by $\mathrm{S} 1$ is wrong.

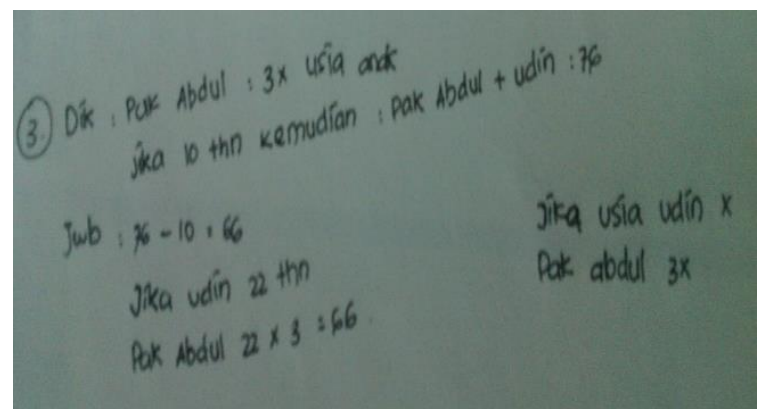

Picture 3 Answer no. 3 research subject 2

Based on the result of S2 work analysis, it is known that $\mathrm{S} 2$ did not do the procedure of Newman stage 4 that is in stage skill process. S2 made mistake that is wrong in doing calculation at problem. Possibility it happened because S2 was wrong in doing transformation not according to what is ordered. This error then the final answer obtained S2 is certainly wrong.

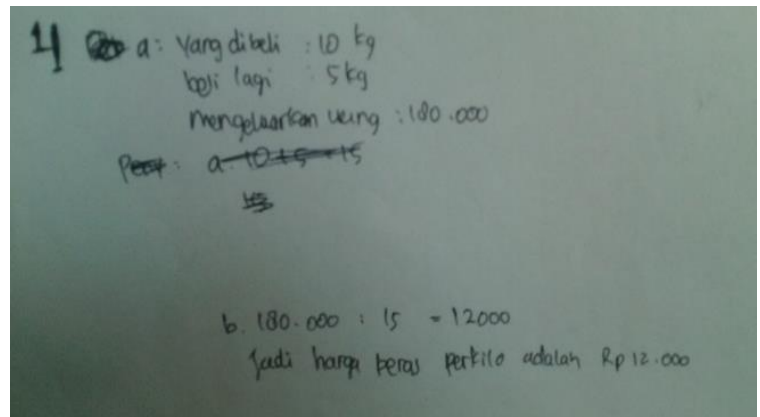

Picture 4 Answer no. 4 research subject 3

Based on the result of S3 work analysis, it is known that S3 did not perform the third step of Newman procedure that is the step of transformation problem, S3 did not write the mathematical model of the problem. So, S3 did not know what approach to use when solving the problem. Then S3 at the 4th stage, the stage of the process of $\mathrm{S} 3$ also made a mistake. The error occurs because S3 did not perform the calculation process with the correct steps. The answer obtained by S3 is correct but at the settlement step because it is less correct not as desired on the problem. Overall, S3 has written the last stages of Newman's procedure, which is writing the final answer on item 4 with the correct answer, even though the steps are not quite right.

This research showed that the cause of the students make mistakes in the transformation stage of the problem because the students did not understand in choosing the approach that will be used in solving the problem and the weakness of the students' ability in changing the mathematical story problem into a mathematical model. The error in the process capability of the problem is caused by the problem transformation done before it is wrong, the student did not understand the concept of algebraic material and determines the process of calculating algebraic operations in solving the story problem. Errors in final answer writing caused the students did not re-examine the sheets of answers done and were not careful in completing the work

\section{CONCLUSION}

Based on the results of research and discussion can be concluded that the type of error that students do when solving the mathematical 
problem of algebraic material based on the Newman's procedure and its causes are: (1) Stages of transformation, mistakes made by the subject consist of not making mathematical models correctly, causing in using formula, because the student is less skilled in making the mathematical model because of lack of practice. (2) Stages of process ability, student mistakes include errors in calculations, errors in algebraic operations, and errors in steps or procedures that are not appropriate. This is due lack of ability to perform algebraic counting operations. (3) Stages of writing the final answer, the mistakes made by the students consist of not making conclusions answers, not finding the final answer, mistake in writing the final result of the answer due to not re-check the answer sheet. The causes are the students did not find the final answer, write conclusions, and hasten in solving them so that students mistakenly write down the final answer.

Based on the results of the research that has been stated before, can be given some suggestions: (1) The teacher should give more problems about the problems of everyday life in order to improve students' ability in solving math problems. (2) Students should also be more serious in following learning for the success of teaching and learning process. (3) It is desirable for the next researcher to conduct similar research with different topics and wider discussion.

\section{REFERENCE}

Jha, S. K. (2012). Mathematics Performance of Primary School Students in Assam (India): An Analysis Using Newman Procedure. International Journal of Computer Applications in Engineering Sciences, 2.

Moleong, L. J. (2005). Metodelogi Penelitian Kualitatif. Jakarta: Rosdakarya

Prakitipong, N., Nakamura, S. (2006). Analysis of Mathematics Performance of Grade Five Student in Thailand Using Newman Procedur. Journal of International Cooperation in Education, 9(1).

Setiyawati, Indra. (2011). Identifikasi Kesalahan dalam Menyelesaikan Soal Cerita Materi Pelajaran Segitiga dan Segiempat Siswa Kelas VII SMP N 5 Depok Sleman Yogyakarta. Yogyakarta: Universitas Negeri Yogyakarta

Soedjadi, R. (2000). Kiat-Kiat Pendidikan Matematika di Indonesia. Jakarta: Direktorat Jenderal Pendidikan Tinggi Departemen Pendidikan Nasional.

Tirtarahardja, Umar dkk. (2005). Pengantar Pendidikan. Jakarta. Rineka Cipta.

White, A. L. (2005). Active Mathematics In Classrooms: Finding Out Why Children Make Mistake - And Then Doing Something To Help Them. Square One, Vol 15, No 4, p.15-19

Zahara, Y. (2015). Analisis Kesalahan Siswa dalam Menyelesaikan Soal Operasi Bentuk Aljabar di Kelas VIII MTsS Lam Ujong Aceh Besar. Skripsi: Universitas Syiah Kuala. 